\title{
Urethral Foreign Body: Evaluation of an Interesting Case Guided by the Literature
}

\author{
Cahit Şahin, Mehmet Kutlu Demirkol, Fehmi Narter, Bilal Eryıldırım, Kemal Sarca
}

\footnotetext{
Department of Urology, Kartal Dr. Lütfi Kırdar Training and Research Hospital, İstanbul, Turkey

Submitted: 01.01.2015 Accepted: 14.04.2015

Correspondence: Cahit Şahin Dr. Lütfi Kırdar Kartal Eğitim ve Araştırma Hastanesi, Üroloji Kliniği, İstanbul, Turkey E-mail: cahitsahin129@gmail.com

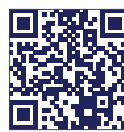

Keywords: Foreign body; urethra; urinary bladder.
}

\begin{abstract}
Urethral foreign body is a rare condition, and while there are many possible reasons, it is generally caused by self-insertion of a foreign object into one's own urethra and requires emergency intervention. Sexual or erotic stimulation, trauma, medical interventions, and psychiatric problems may play a role in etiology. Radiological findings are important in order to obtain information about the foreign body and make accurate diagnosis, and treatment of this condition may require various instruments due to adjacent organ injury. Presently described is effort to determine possible causes of bladder gas, considered evidence of severe urological problem, and its association with urethral foreign body with a lumen. Treatment approaches to urethral foreign body as reported in the literature are also discussed.
\end{abstract}

\section{INTRODUCTION}

Although rarely seen, urethral foreign body may have many etiologies. However, it is usually the result of patient inserting the foreign object into the urethra, requiring emergency intervention.

Insertion of foreign body into genitourinary tract is frequently attempted for sexual satisfaction and orgasm, or it may also be the result of medical intervention. ${ }^{[1]}$ In a substantial number of cases, psychiatric disorders play an important role. ${ }^{[2,3]}$ Foreign bodies inserted into urethra include items such as a pencil, thermometer, toothbrush, wax, and similar objects. ${ }^{[2,4-6]}$ Adjacent organ injury is determinative in the choice of appropriate treatment.

The present case report is an examination of association between intravesical gas, considered to be indication of serious urological problem, and urethral foreign body with a lumen. In addition, relevant treatment approach is analyzed.

\section{CASE REPORT}

A 67-year-old male patient with diabetes mellitus (DM) presented at emergency polyclinic with complaints of dysuria, penile swelling, and pain. He had inserted a ballpoint pen into his urethra $1 \frac{1}{2}$ months earlier in an effort to resolve severe urethral itching (Figure I). He had unsuccessfully tried to remove the object many times. On physical examination, foreign body measuring $4-5 \mathrm{~cm}$ was palpated I cm from external meatus. Penis was hyperemic and edematous, and external meatus was constricted as result of meatal edema.

Laboratory analyses revealed no growth on urine cultures, but leukocyturia was detected. Intravesical gas and intraurethral object with a lumen were observed in pelvic computed tomography (CT) images (Figure 2a, b). Diagnosis of urethral foreign body inside anterior urethra was made, and urethroscopy was attempted with sedoanalgesia. However, foreign body near meatus prevented intraurethral engagement of cystoscope. Meatotomy was performed in order to reach the object, which was carefully extracted using a surgical clamp. Following removal of the object, cystoscopy was performed, which revealed hyperemic and edematous areas. Urethral rupture was not detected. Bladder was hyperemic; however, no perforation or fistula 
that might cause intravesical gas formation was found. Patient was discharged on postoperative first day with prescriptions for analgesics and antibiotherapy.

\section{DISCUSSION}

Urethral foreign body is an emergency case that can have various etiologies. Patient may have inserted foreign body into urethra or condition may have accidental or iatrogenic causes. ${ }^{[l]}$ Patient inserting foreign body to relieve severe urethral itching, as in present case, is a rarely encountered condition. ${ }^{[7]}$ Urethral irritation may be seen more frequently in diabetic patients as they are more prone to infection. ${ }^{[2]}$

Patients with urethral foreign body may present with complaints of painful urination, macroscopic hematuria, urinary urgency, and recurrent urinary infections. ${ }^{[2]}$ Patients are generally embarrassed to explain their situation, which leads to delay in diagnosis. In particular for patients with DM, foreign bodies in situ long-term can lead to complications such as infection, sepsis, and necrosis. ${ }^{[2]}$ In the evaluation of the patient, shape, size, other characteristics of the foreign body, length of time the object has been in place, and psychiatric condition of the patient should be determined, and a meticulous physical examination should be performed..$^{[5]}$

In most cases, pelvic radiograms can provide adequate information about foreign body; however, for non-opaque foreign bodies, conventional radiograms may not yield sufficient information. In the present case, foreign body was not opaque, and therefore could not be visualized on pelvic radiograms. Additional methods that may be used to obtain further information include ultrasound (US) and $\mathrm{CT}^{\left[{ }^{[4]}\right.}$ Rahman et al. performed a study on 17 patients with intravesical foreign bodies, and authors reported that they could palpate all intraurethral foreign bodies. They indicated that in 13 cases, anteroposterior pelvic radiograms were adequately diagnostic, and only in 3 patients were US and $C T$ required. ${ }^{[5]}$ An additional advantage of contrast CT

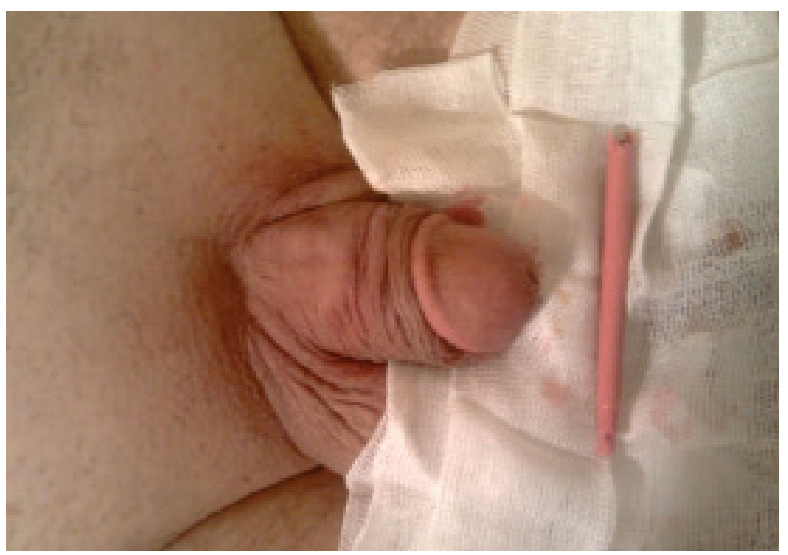

Figure 1. A ballpoint pen extracted from urethra.
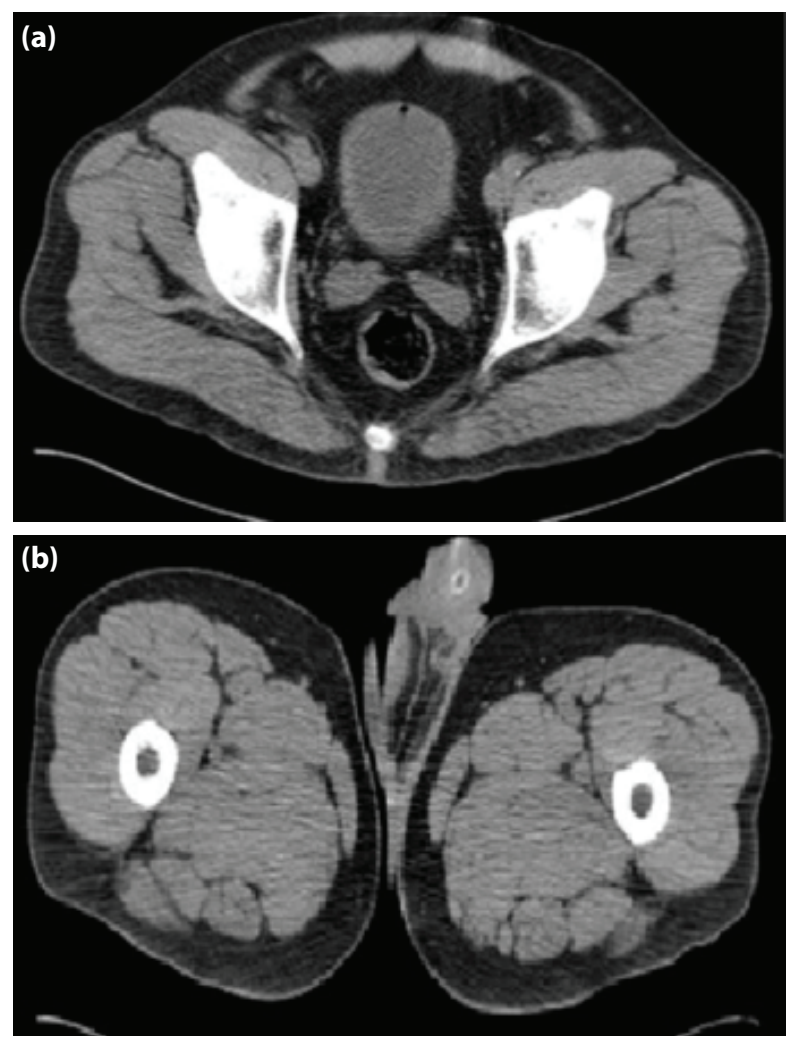

Figure 2. (a) Image of the intravesical gas. (b) CT image of the foreign body with lumen.

is that it can provide important information about adjacent organ injury and presence of enterovesical fistula ${ }^{[8]} \mathrm{CT}$ in present case revealed presence of intravesical gas as well as intraurethral foreign body.

Attempts to remove foreign body or push it into intravesical cavity may cause object to migrate into bladder, facilitated by effects of perineal contractions. ${ }^{[9]}$ As in this case, an object with a lumen may deliver outside air to the bladder. Intravesical gas may indicate serious conditions, and in differential diagnosis, uroenteric fistula, anaerobic infection, trauma, and any recent endoscopic intervention concerning urinary system should be considered.

Furthermore, in diabetic patients, carbon dioxide formed as result of fermentation of high glucose content urine after infection may induce gas formation in urinary system. ${ }^{[10]}$

Treatment modality selected will vary based on number, location, and size of foreign bodies. Extraction of the foreign object without injuring urethra, and relief of obstruction are primary goals. Most cases can be treated with endoscopic means, though in some cases open surgery may be required..$^{[5]}$ Urethral erosion caused by foreign body, forceful manipulations during extraction, and difficulty encountered during intraurethral advancement of endoscopic instruments may necessitate external meatotomy or open surgery. ${ }^{[6]}$ 
In the present case, intraurethral foreign object was impacted near the meatus and did not allow for insertion of urethroscope. Following meatotomy, foreign body was successfully extracted using surgical clamp without damaging the urethra. After procedure to remove the object, urethra and bladder should be evaluated with urethrocystoscopy. ${ }^{[I]}$ In present case, postoperative urethroscopy revealed only patchy areas of hyperemia and edema. It should not be forgotten that following extraction of intraurethral foreign bodies, urethral strictures can develop, and postoperative follow-up should be recommended.

Psychiatric disorders are frequently associated with instances of urethral foreign body. ${ }^{[2,3]}$ However, patient may decline recommendation of psychiatric evaluation, as was the case with present patient.

In conclusion, foreign body with a lumen inserted into urethra associated with intravesical gas may be resolved without development of uroenteric fistula, perforation or infection. Although urethral foreign bodies are usually removed endoscopically, when necessary, carefully performed open surgery can yield effective outcome.

\section{REFERENCES}

1. Martínez-Valls PL, Honrubia Vilchez B, Rodríguez Tardido A, Izquierdo Morejón E, Pietricica BN, Rosino Sanchez A, et al. Voiding symptoms as presentation of an intravesical foreign body. Arch Esp Urol 2008;61:781-5.

2. van Ophoven A, deKernion JB. Clinical management of foreign bodies of the genitourinary tract. J Urol 2000;164:274-87.

3. Walter G. An unusual monosymptomatic hypochondriacal delusion presenting as self-insertion of a foreign body into the urethra. Br J Psychiatry 1991;159:283-4.

4. Ku JH, Lee CS, Jeon YS, Kim ME, Lee NK. A Foreign body in the urethra: a case report. Korean J Urol 1997;38:219-21.

5. Rahman NU, Elliott SP, McAninch JW. Self-inflicted male urethral foreign body insertion: endoscopic management and complications. BJU Int 2004;94:1051-3.

6. Moon SJ, Kim DH, Chung JH, Jo JK, Son YW, Choi HY, et al. Unusual foreign bodies in the urinary bladder and urethra due to autoerotism. Int Neurourol J 2010;14:186-9.

7. Sukkarieh T, Smaldone M, Shah B. Multiple foreign bodies in the anterior and posterior urethra. Int Braz J Urol 2004;30:219-20.

8. Rowner ES. Urinary tract fistulae. In: McDougal WS, Wein AJ, Kavoussi LR, Novick AC, Partin AW, Peters CA, et al., editors. Campbell-Walsh urology. 10th ed. Philadelphia, PA: Elsevier Saunders; 2012.p. 415-21.

9. Sunwoo IS, Kwon CH, Kim YS, Chung KS, Kim JC. Five cases of foreign bodies in the bladder. Korean J Urol 1980;21:82-5.

10. Galiano Baena JF, Caballero Romeu JP, Galán Llopis JA, Leivar Tamayo A, Lobato Encinas JJ. Emphysematous cystitis. Case report and review of literature. Actas Urol Esp 2008;32:948-50.

11. Ali Khan S, Kaiser CW, Dailey B, Krane R. Unusual foreign body in the urethra. Urol Int 1984;39:184-6.

\section{Üretral Yabancı Cisim: Illginç Bir Olgunun Literatür Eşliğinde Değerlendirilmesi}

Üretral yabancı cisim nadir görülen, farklı sebepleri olmakla birlikte sıklıkla kişinin kendi üretrasına yabancı cisim tatbiki ile oluşan ve acil girişim gerektiren bir durumdur. Etiyolojide, seksüel veya erotik uyarı sağlama, travma ve tıbbi girişimlerin yanı sıra psikiyatrik problemler da bu durumda önemli rol oynamaktadır. Çeşitli araçlarla gerçekleşen bu durum tedavi planında komşu organ yaralanması ve yabancı cisim hakkındaki bilgi sağlaması ile radyolojik bulgu ve tanı önemlidir. Bizim amacımız, ciddi ürolojik problemlerin bulgusu sayılan mesane gazının lümenli üretral cisim ile birlikteliğini ve olası nedenlerini ortaya koymaktır. Ayrıca üretral yabancı cisimde tedavi yaklaşımlarını literatür eşliğinde tartıştırmaktır.

Anahtar Sözcükler: Yabancı cisimler; üretra; mesane. 